\title{
Towards a Dialect History of the Baggara Belt
}

\author{
Stefano Manfredi ${ }^{1, *(D)}$ and Caroline Roset ${ }^{2}$ \\ 1 SeDyL (CNRS UMR8202, INALCO, IRD UR135), Campus CNRS de Villejuif, 7 Rue Guy-Môquet, \\ 94801 Villejuif, France \\ 2 Department of Arabic Language and Culture, Faculty of Humanities, University of Amsterdam, \\ 1012 WX Amsterdam, The Netherlands; c.j.roset@uva.nl \\ * Correspondence: stefano.manfredi@cnrs.fr
}

check for updates

Citation: Manfredi, Stefano, and Caroline Roset. 2021. Towards a Dialect History of the Baggara Belt. Languages 6: 146. https://doi.org/ 10.3390/languages6030146

Academic Editors: Simone Bettega and Roberta Morano

Received: 26 June 2021

Accepted: 23 August 2021

Published: 30 August 2021

Publisher's Note: MDPI stays neutral with regard to jurisdictional claims in published maps and institutional affiliations.

Copyright: (c) 2021 by the authors. Licensee MDPI, Basel, Switzerland. This article is an open access article distributed under the terms and conditions of the Creative Commons Attribution (CC BY) license (https:// creativecommons.org/licenses/by/ $4.0 /)$.

\begin{abstract}
The Baggara Belt constitutes the southernmost periphery of the Arabic-speaking world. It stretches over $2500 \mathrm{~km}$ from Nigeria to Sudan and it is largely inhabited by Arab semi-nomadic cattle herders. Despite its common sociohistorical background, the ethnography of Baggara nomads is complex, being the result of a long series of longitudinal migrations and contacts with different ethnolinguistic groups. Thanks to a number of comparative works, there is broad agreement on the inclusion of Baggara dialects within West Sudanic Arabic. However, little or nothing is known of the internal classification of Baggara Arabic. This paper seeks to provide a comparative overview of Baggara Arabic and to explain dialect convergences and divergences within the Baggara Belt in light of both internally and externally motivated changes. By providing a qualitative analysis of selected phonological, morphosyntactic, and lexical features, this study demonstrates that there is no overlapping between the ethnic and dialect borders of the Baggara Belt. Furthermore, it is argued that contact phenomena affecting Baggara Arabic cannot be reduced to a single substrate language, as these are rather induced by areal diffusion and language attrition. These elements support the hypothesis of a gradual process of Baggarization rather than a sudden ethnolinguistic hybridization between Arab and Fulani agropastoralist groups. Over and above, the paper aims at contributing to the debate on the internal classification of Sudanic Arabic by refining the isoglosses commonly adopted for the identification of a West Sudanic dialect subtype.
\end{abstract}

Keywords: Arabic; Sudanic Arabic; Baggara; comparative dialectology

\section{Introduction}

In his early account of the Shuwa Dialect of Bornu, Nigeria and of the Region of Lake Chad, the British colonial governor G. J. Lethem (1920, p. xi) stated that Nigerian (i.e., Shuwa) Arabic "is part of the Arabic dialects of the Sudan, of which Shuwa is the westernmost". By using these words, Lethem was most likely the first to recognize "the dialects of the Sudan' as a homogenous dialect group, distinct from other Arabic varieties (i.e., Maghrebi, Levantine, Gulf, etc.). Later on, Blanc (1971) adopts the label 'Sudanic Arabic' for referring to the dialect continuum running across the vast region delimited by Lake Chad (Nigeria) in the west, by the Red Sea coast (Sudan) in the east, by Lake Nasser (Egypt) in the north, and by the Nuba Mountains (Sudan) in the South. According to Blanc (1971, p. 503) Sudanic Arabic "does not fit too neatly into either the East-West or the nomadic-sedentary dichotomy, though on the whole it is more Eastern than Western and more nomadic than sedentary". In spite of the vagueness of the dialect portrait drawn by Blanc, both historical and linguistic data unmistakably point out that Sudanic Arabic mainly (but not exclusively) emerged following the penetration of Arabic-speaking nomadic groups from Upper Egypt into Sudan in the first half of the 14th century (cf. 2, see also Thomas A. Leddy-Cecere this special issue). During the last decades, several studies (Blanc 1971; Kaye 1976; Owens 1985, 1993b; Roth-Laly 1994a; Manfredi 2012) have identified a number of isoglosses for pinpointing the Sudanic area within the wider Arabicspeaking world. These Pan-Sudanic features include: 
- The phonological reflexes ${ }^{*} \mathrm{q}>\mathrm{g}(\mathrm{k}),{ }^{*} \mathrm{t}>\mathrm{t}$ ( $\left.\mathrm{t}\right) ;{ }^{*} \mathrm{~d}>\mathrm{d}$ (d) (e.g., * baqar $>$ bagar 'cows'; *tawb >tōb 'women dress'; *kadd $\bar{a} b>$ kaddāb 'liar');

- $\quad$ The presence of the phoneme č (e.g., čalbaq 'stick.3SG.M');

- The partial preservation of an etymological a in prepausal position (e.g., gul-t(a) 'say-1SG/2SG.M', dagga 'hit.3SG.M');

- $\quad$ The generalization of the preformative a- in imperative forms (e.g., a-gif 'IMP-stop');

- The presence of postnominal demonstrative determiners lacking the etymological element *ha- (e.g., $d a$ 'PROX.SG.M');

- The large use of the lexemes $a b \bar{u}$ 'father' and umm/amm 'mother' as compound formatives (e.g., abu gurūn 'rhino', aṃm garn 'ground hornbill');

- The presence of ideophones as a lexical category (ahmar čall red IDPH 'bright red').

Concerning the internal classification of Sudanic dialects, Kaye (1976) examines selected phonological and morphological features of Chadian and Sudanese Arabic in light of Ferguson's monogenetic theory of dialect emergence and stresses the relative homogeneity of these varieties. Owens (1993a), in contrast, proposes a patchwork approach that does not reveal any eco-linguistic difference between 'Bedouin' and 'Sedentary' dialects, while showing clear affinities between Sudanic and Upper Egypt Arabic. Roth-Laly (1994a, 1994b), on her part, stresses the generalization of traditional 'Bedouin' features in Sudanic Arabic and identifies new local isoglosses for opposing 'Bedouin' to 'Sedentary' dialects across the Sudanic area. Regardless of their different approaches, the previously mentioned scholars agree in identifying two main dialect sub-types within Sudanic Arabic: West Sudanic Arabic (henceforth 'WSA') and East Sudanic Arabic (henceforth 'ESA'). WSA encompasses the dialects spoken in Nigeria (Lethem 1920; Owens 1993a, 1993b), Cameroon (Owens 1993a), and Chad (Carbou 1913; Roth-Laly 1972, 1979; Hagège 1973; Decobert 1985; Zeltner and Tourneux 1986; Abu-Absi 1995; Jullien de Pommerol 1999a, 1999b) as well as in the western Sudanese provinces of Darfur and Kordofan (Manfredi 2010, 2012, 2013; Roset 2018). ESA covers the remaining parts of the Sudanic dialect area (i.e., the central and eastern part of Sudan) and it includes the koine of the capital Khartoum (i.e., Khartoum or Sudanese Arabic, Bergman 2002; Dickins 2011) and the rural dialects spoken in the Gezira and Butana regions (Reichmuth 1983). Even if this geographical split between WSA and ESA is supported by strong linguistic evidence, it hardly reflects the high degree of diatopic and eco-linguistic variation affecting Sudanic Arabic. In this regard, it is worth remarking that Hillelson $(1925$, p. xv) distinguishes at least four distinct dialect subtypes in Sudan, counting:

"The speech of the Northern Sudan, including Berber Province and the Arabic-speaking parts of Dongola; the speech of the Central Sudan, including Omdurman, the Gezira, and the country to the east of the Blue Nile; the idiom of the Western Sudan, embracing the White Nile, Kordofan and Darfur; and the dialect of the Baggara tribes. It should further be noted that the speech of nomad Arabs everywhere differs from that of the settled population."

Hillelson's introduction to his Sudanese Arabic dictionary therefore warns about the specificity of the "speech of nomad Arabs" in Sudan of which the semi-nomadic Baggara are part. In light of the above, this paper seeks to answer the question of to what extent Baggara Arabic constitutes a homogenous dialect sub-type within West Sudanic Arabic. For this aim, we provide a comparative overview of five different Baggara dialects in order to assess their degree of structural proximity and to explore the sociohistorical factors underlying the diffusion of linguistic innovations across the Baggara Belt.

A preliminary version of this paper was presented at the 47th North Atlantic Conference on Afroasiatic Linguistics, INALCO, Paris, 24-25 June 2019. The paper is organized as follows. In Section 2, we offer a sociohistorical and linguistic introduction to the Baggara Belt. Section 3 briefly presents the data and the sources used for our comparative analysis. In Section 4, we explore the diatopic variation affecting a number of phonological, morphosyntactic, and lexical features in Baggara Arabic, while trying to reconstruct both internally and externally motivated diachronic changes. Section 5 finally attempts at re- 
constructing the dialect history of the Baggara Belt and provides some new hints on the internal classification of West Sudanic Arabic.

\section{The Baggara Belt: Sociohistorical and Linguistic Background}

MacMichael (1922, p. 271) argues that "Baggara means no more than cattlemen". Accordingly, the term Baggara (from the agentive noun PL baggāra 'cattlemen', SG.M/F baggāri/baggāriye) has neither ethnic nor genealogical pertinence, as it rather stresses the specificity of an agro-pastoral system of production based on cattle herding and sorghum cropping (Cunnison 1966, p. 10; Teitelbaum, 1984; Braukämper 1993, p. 14; Manfredi 2010, p. 10). There is a broad agreement on the fact that the center of origin of the Baggara tribes is to be found in present-day Chad. Nevertheless, two contrasting hypotheses have been put forward to trace back the way by which Arab nomads reached Chad. On the one hand, Carbou (1913, p. 4) and Henderson (1939, p. 52) allege that Arab nomadic groups entered Chad via the Fezzan area in Libya. In this perspective, the Baggara should be seen as an offshoot of the Arab groups that pushed southwards from Maghreb to central Africa following the Hilalian invasion in the 11th century. Even if this hypothesis is corroborated by Baggara oral traditions referring to Abu Zayd al-Hilali (Manfredi 2010, p. 12), there are neither historical nor linguistic arguments supporting the suggestion of a Maghrebi origin of Baggara groups. On the other hand, MacMichael (1922, p. 275) affirms that:

"On the migration of these Arabs from the east there cannot be the least doubt. They advanced gradually through the Negroland. [...] Their dialect is quite different from the Maghrebi, while in many respects it still preserves the purity and the eloquence of the language of Hijaz."

Accordingly, the Baggara would have split apart from the Juhayna groups that penetrated Sudan from Upper Egypt (Cunnison 1971). This latter hypothesis is also supported by Braukämper (1993, p. 19) who links the beginning of the westwards migration of the Baggara ancestors with the famines that affected the Nile valley during the second half of the 15th century. Further to this, there is an unmistakable linguistic evidence pointing to an influx of Upper Egypt Arabic into Baggara dialects (Owens 1993b, cf. 4.1).

Against this backdrop, the question of when and how Arab nomads abandoned camels in favor of cows remains quite controversial. Braukämper (1993, pp. 17-20) suggests that the Baggarization process started after the overthrow of the Tunjur dynasty in Wadai (eastern Chad) in 1635. This event, which is referred to as Šaggat al-Nāga 'the division of the she-camel' in Chadian and Sudanese oral traditions (MacMichael 1912, p. 151), would have led to a southward movement of the Arab groups that supported the Tunjur dynasty. Following this population displacement, Arab nomads came into contact with Fulani cattle herders settled in the low rainfall savannas and eventually switched from camel to cattle breeding, while maintaining Arabic as their ancestral language. At variance with this hypothesis, Owens (1993b, p. 166; 2003, p. 723), making use of both historical and linguistic data, claims that the Baggarization process took place as early as the 15th century in the area of Kanem-Bornu and Baguirmi (western Chad), since Arabs and Fulani had already reached this region by that time.

In the present paper, we stress instead that Baggarization should be seen as a progressive process of socio-economic integration rather than a sudden ethnolinguistic hybridization induced by the adaptation to new ecological conditions. We therefore argue that the need for economic differentiation of both sedentary and nomadic groups is the main factor behind the emergence and the diffusion of the Baggara semi-nomadic production system across eastern Sahel. In this regard, Haaland (1969) convincingly shows that the Baggara tribes of Darfur (i.e., Ta'isha, Rizeygāt, Bānu Halba, cf. Figure 1) are characterized by the incorporation of local sedentary groups, as cattle-owning Fur farmers frequently establish themselves as Baggara nomads. In a similar manner, Manfredi (2010) observes that the Hawāzma, the larger Baggara tribe of Sudan (cf. Figure 1), are mixed with both sedentary non-Arab groups of Kordofan (mainly Nuba) and with camel-herders coming from eastern Sudan (the so-called $A b b \bar{a} l a$ ). The same is true for the Bānu Sulēym tribe of the White 
Nile (cf. Figure 1) who integrated eastern Arab groups (mainly Ahāmda) as well as the sedentary Shilluk of South Sudan. The fact that Baggarization is a gradual and ongoing process of socio-economic integration is also revealed by recent genetic studies (Čížková et al. 2017; Priehodová et al. 2020; Nováčková et al. 2020), which indicate that, despite a remarkable degree of ethnic admixture between agro-pastoralist groups of the Sahel, biological contacts between Fulani and Arab nomads must have been rather infrequent. These circumstances support the idea that the Baggarization process took place at different times, across a wide geographical front, and involved different Arab and non-Arab groups. As we will see, this underlying ethnolinguistic heterogeneity is the main reason for the absence of interference from a single substrate language (i.e., Fulani) in Baggara Arabic cf. $4.1,5)$.

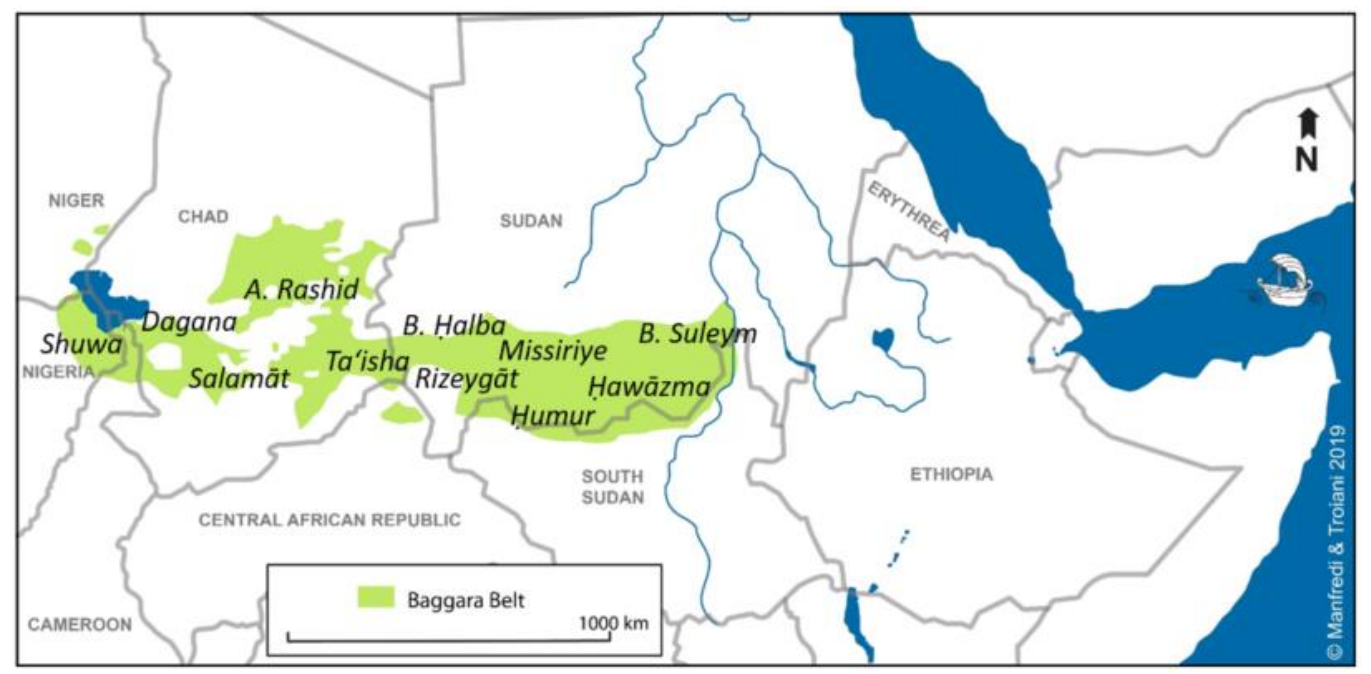

Figure 1. The Baggara Belt and its main tribes.

At the present time, Baggara Arabs are involved by different dynamics of language contact, mainly depending on their degree of sedentarization and their relative demographic weight. On the one hand, the Shuwa of north-eastern Nigeria represent a largely sedentarized linguistic minority. Accordingly, speakers of Nigerian Arabic present a high degree of bilingual proficiency in Kanuri and/or Hausa, while maintaining transmission of their ancestral language to younger generations (Owens 2020, p. 177). On the other hand, Baggara Arabs of Sudan represent an ethnolinguistic majority and they still hold on to their semi-nomadic production system. Accordingly, they have hardly developed any bilingual competence in the different languages of sedentary communities of Darfur and Kordofan. Nevertheless, due the dominant position of Arabic in Sudan, western Baggara groups are affected at different degrees by dialect mixing and leveling towards Sudanese Arabic (Manfredi 2013, cf. 5).

Finally, it is worth remarking that Baggara Arabic historically represented the target language of non-Arab sedentary bilingual communities of Chad and western Sudan. Most sedentary communities dispersed across the West Sudanic dialect area speak Arabic as a vehicular language (see Roth-Laly 1979 for the variety of Abbeche, eastern Chad). In such a context, an increasing number of town dwellers in western Sudan (Darfur and Kordofan) are shifting from their ancestral languages to Arabic (Manfredi 2012; Roset 2018). It is thus not surprising that Baggara dialects and the Arabic varieties spoken by non-Arab sedentary groups display a high degree of mutual intelligibility. However, we will also see that, due to the stronger influence from local languages, the Arabic varieties of sedentary communities display a number of divergent morpho-phonological features (e.g., depharyngealization, lack of implosive consonants, weakening of F.PL as morphological category, cf. 4.1,5) that allow us to draw a distinction between Baggara and 'Sedentary' West Sudanic Arabic. 


\section{Sample and Sources}

The data used for our comparative overview of Baggara Arabic come from different sources. First, we refer to a heterogeneous literature that provides linguistic information on different Baggara dialects of Chad and Sudan. These bibliographical sources have been completed by new first-hand data gathered during fieldwork in the White Nile region (Sudan) in 2018. The data and the sources can be summarized as follows:

- $\quad$ Nigerian Baggara Arabic (NA) Shuwa tribe (Carbou 1913; Lethem 1920; Owens 1993a, 1993b);

- $\quad$ Baguirmi Baggara Arabic (BgA) Walād 'Ali tribe (Zeltner and Tourneux 1986; Decobert 1985);

- $\quad$ Batha Baggara Arabic (BaA), Walād Rashid tribe (Decobert 1985);

- Kordofanian Baggara Arabic (KA), Hawāzma and Missiriye tribes (Manfredi 2010, 2013); and

- White Nile Baggara Arabic (WA), Bānu Sulēym tribe (own fieldwork data).

For the aims of this study, we will also make reference to Shukriyya Arabic (ShA) (Reichmuth 1983) which provides room for comparison between Baggara Arabic and an Eastern Sudanic dialect. Moreover, we will largely disregard both ESA and WSA Sudanic sedentary dialects in the quest to provide evidence for dialect convergence or divergence within the Baggara Belt. Nonetheless, the comparison between Baggara Arabic and the sedentary dialects of Chad and Sudan offers a number of interesting hints concerning the internal classification of WSA as a whole (cf. 5). The geographical distribution of the dialects included in our sample is shown in Figure 2.

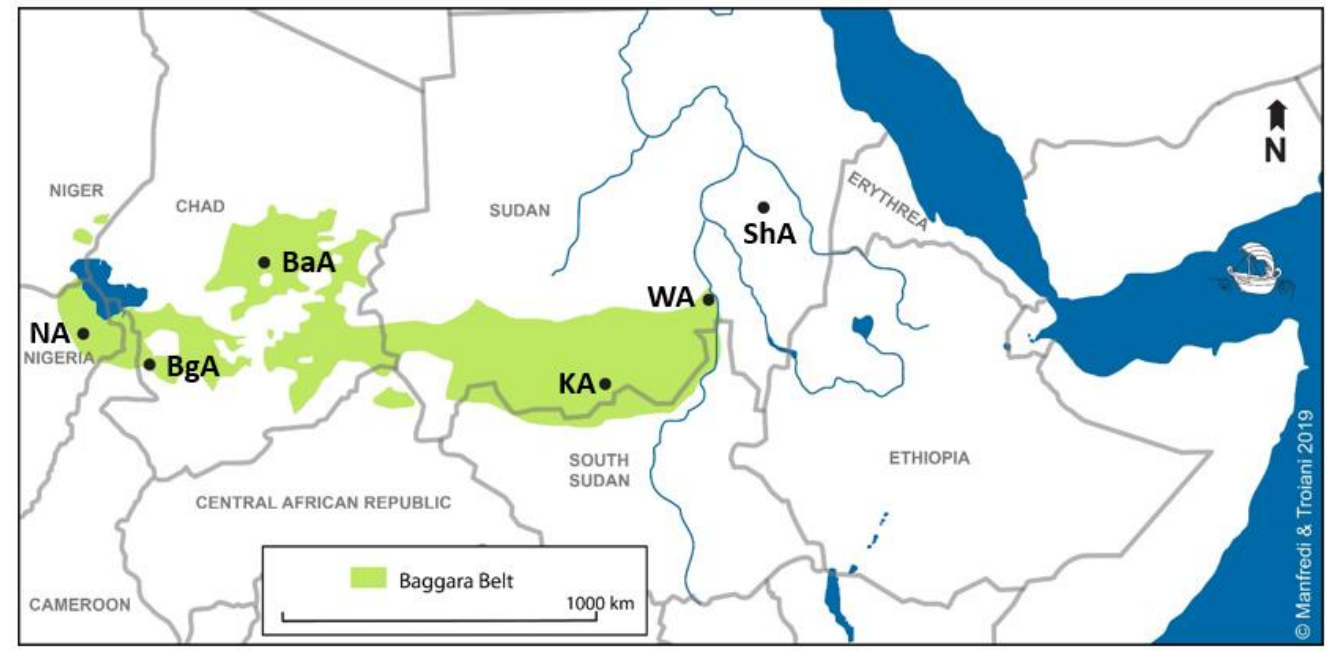

Figure 2. The geographical distribution of the Arabic dialects of the sample.

\section{Assessing Diatopic Variation across the Baggara Belt}

In this section, we provide a qualitative overview of selected dialect features of Baggara Arabic. The analysis is primarily intended to show the geographical distribution of Figure 2 these features and to explain the dynamics of dialect convergences and divergences across the Baggara Belt. For this purpose, we will analyze phonological (4.1), morphosyntactic (4.2), and lexical (4.3) isoglosses from the perspective of internally motivated, and externally motivated as well as multi-causal changes.

\subsection{Phonological Features}

If we omit a few phonological features attested all across the Baggara Belt (ex. ${ }^{*}-a>-e$ in pre-pausal position, e.g., "kabīr-a > kabìr-e "big (F)"; presence of backness vowel harmony, e.g., *simsim > *sumsim > sumsum "sesame"), Baggara Arabic is affected by a high degree of phonological variation. This is actually not surprising as phonological features typically have a low stability gradient and they are therefore more likely to undergo both internally 
and externally induced changes. If we take a look at the domain of pharyngealized (i.e., empathic) consonants, Baggara Arabic presents a number of phonological splits producing a rich set of non-etymological pharyngealized consonants.

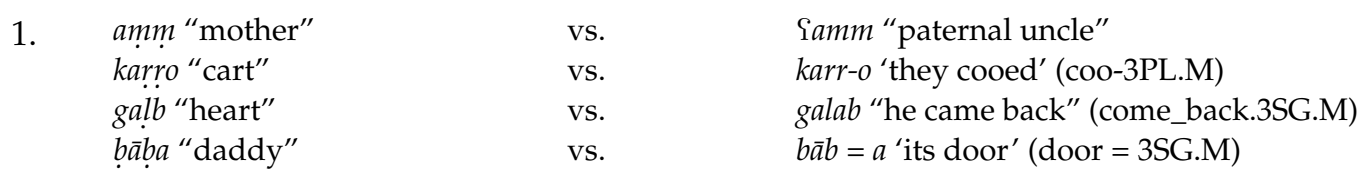

However, the etymological pharyngeal consonants $* h$ and ${ }^{*} \mathrm{C}$ are diversely affected by depharyngealization. Owens $(1993 b, 2020)$ claims that the phonological developments $* h>h$ and ${ }^{*}>>1, \varnothing$ represent a defining feature of WSA and he further argues that "this change could have been due to substratal influence, originally non-native speakers having difficulty in mastering h.ศ." (1993b, p. 163). This hypothesis is indeed plausible for sedentary verities of WSA spoken by non-Arab groups, which are characterized by the complete loss of pharyngeal consonants (Jullien de Pommerol 1999b, p. 11; Roth-Laly 1972, p. 68; Manfredi 2013, p. 24; Roset 2018, p. 18). However, the situation is quite different when it comes to the distribution of ${ }^{*} h$ and ${ }^{*} \mathrm{C}$ across the Baggara Belt.

2. NA-*hilim > hilim 'he dreamt' (dream.3SG.M), *gaiad > ga?ad 'he sat down' (sit.3SG.M) BbA-*hille > hille 'village', *nạla > na?ala 'sandal'

BaA-iud 'stick', hille 'village'

KA-hilim 'he dreamt' (dream.3SG.M), gaiad 'he sat down' (sit.SG.M)

WA-halla 'he released' (release.3SG.M), ga ad 'he sat down' (sit.SG.M)

Example (2) shows that, with the exception of NA and BbA, Baggara dialects retain pharyngeal consonants. Furthermore, KA gives evidence of pharyngealization of the etymological glottal stop in intervocalic position (e.g., ${ }^{*} r a ? \bar{a}>$ ri $\mathrm{Y} a$ see.3SG.M, Manfredi 2010, p. 232). Further to this, at the beginning of the 20th century, Carbou (1913) and Lethem (1920) reported the presence of pharyngeal consonants in western Chad and Nigeria, respectively. This state of affairs inevitably weakens the hypothesis that depharyngealization in western Baggara dialects is a product of substrate interference due to second language acquisition. Contrariwise, if we consider that Nigerian Arabs have developed a high bilingual proficiency in Kanuri and / or Hausa following their progressive sedentarization (cf. 3), a more plausible hypothesis is that depharyngealization is a relatively recent phenomenon triggered by language attrition. In this perspective, speakers of NA gradually lost their ability to produce the etymological sounds $* h$ and ${ }^{*}$ and they replaced them with their laryngeal and glottal counterparts (cf. Lucas and Manfredi 2020, p. 6). All things considered, depharyngealization is not a defining feature of WSA, but it is rather an important phonological feature distinguishing Nigerian and Baguirmi Arabic from other Baggara varieties.

The innovative nature of the westernmost Baggara phonologies (i.e., NA and BgA, cf. Figure 3) is confirmed by other features differentiating them from eastern Baggara varieties. This is the case of the insertion of an epenthetic vowel after $x, h$, and $q$, whose occurrence is also limited to Nigeria and western Chad.

3. NA, BbA *ahmar > ahamar "red", axdar > axadar "green"

BaA, KA, WA, ShA ahmar "red", axdar "green"

Owens (1993b, pp. 96-97, 161) and Owens and Jidda (2006, p. 710) consider guttural epenthesis a generalized feature of WSA. This is because this syllable change is also attested in most sedentary dialects of Chad and western Sudan (Jullien de Pommerol 1999b, pp. 28-29; Roth-Laly 1979, pp. 107-8; Roset 2018, p. 29). In this general context, eastern Baggara dialects (BaA, KA, and WA) as well as ShA are characterized by a higher degree of stability of syllable structures, as they do not display guttural epenthesis.

An important segmental feature subjected to diatopic variation across the Baggara Belt is the reflex of the etymological dental emphatic ${ }^{*} t$. It has been argued that the common reflex of ${ }^{*} t$ in WSA is an implosive emphatic $d$. (Owens and Jidda 2006, p. 709). Nonetheless, sedentary dialects of Chad and western Sudan have $t$ as the most common reflex of the 
etymological voiceless dental emphatic (Jullien de Pommerol 1999b, pp. 28-29; Roth-Laly 1972, p. 69; Manfredi 2013, p. 24; Roset 2018, p. 41). Looking at Baggara dialects, the implosive emphatic $d$. presents different phonological statuses.
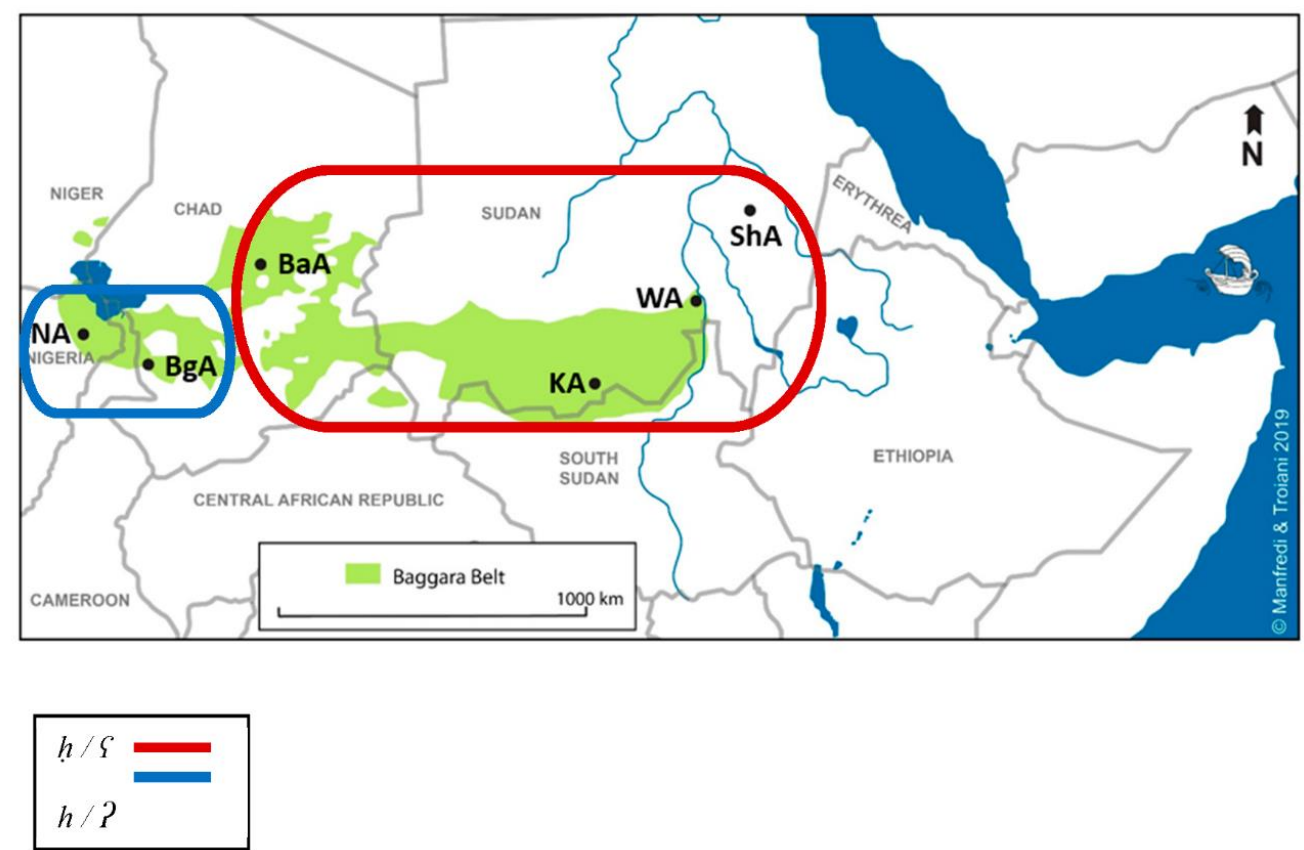

Figure 3. Depharyngealization.

4. NA *rabat > rabad 'he tied' (tie.3SG.M),

BgA tawwal 'he was late' (be_late.3SG.M)

KA taršān [d arša:n], tīn 'mud'

WA tawwa 'he lifted' (lift.3SG.M)

If $d$. is a full-fledged phoneme in NA, in KA the implosive emphatic $[d$ ] $]$ only occurs as an allophone of $t$ before open vowels (Manfredi 2010, p. 44). The other three Baggara varieties included in our sample align to ESA dialects in presenting an etymological ${ }^{*} t$ (see Reichmuth 1983, p. 44 for ShA). Concerning the origin of the implosive realization of ${ }^{*} t$, Owens (2020, p. 179) argues that it represents a possible candidate for substrate interference in WSA, as Fulani also has a dental implosive consonant. This hypothesis, however, neglects the fact that Upper Egypt dialects also present a glottalized realization for the etymological ${ }^{*} t$. Khalafallah $(1969$, p. 29), for example, states that $t$ and its glottalized reflex are in partial complementary distribution in Sa'idi Arabic. Behnstedt and Woidich (1985), on their part, claim that a glottalized realization of $t$ is attested from Asyut to Aswan. More recently, Schroepfer (2016, p. 152) shows that, similar to what is observed in $\mathrm{KA}$, in Aswan Arabic, $t$ is in variation with $[d]$ in pre-vocalic position. Accordingly, it seems plausible to think that the origin of $d$. is an inherited feature from Upper Nile dialects rather than a phonological innovation due to substrate interference from Fulani. In this perspective, the phonological status of $d$ in NA would have been strengthened only at a later stage due to broader areal diffusion, as most local languages of the ChariBaguirmi region present implosive consonants (Maddieson 2013). Conversely, the absence of the reflex $d$ in the other Baggara varieties could be explained in light of dialect leveling towards regional standards lacking glottalized realizations (i.e., Sudanese and Chadian Arabic, $t)$. All things considered, the complex geographic distribution of the implosive emphatic $d$. across the Baggara Belts should be interpreted as the result of a multi-causal change involving language inheritance from Upper Nile dialects, areal diffusion from local languages in the Lake Chad region, and dialect leveling.

The phonological reflexes of the etymological voiced velar fricative ${ }^{*} \dot{g}$ are also variably affected by (im)plosivization. 
5. $\quad$ NA * $\dot{a} \bar{a} d i>q \bar{a} d i$ 'there', *šs $\dot{g} u l>$ suqul 'thing'

BgA, BaA *gayyar > G'ayyar 'he changed' (change.3.SG.M), *šug்ul > šuG'ul 'thing'

KA * ganam > qanam [ $g$ anam] 'goats', *šuguul > šoqol 'thing'

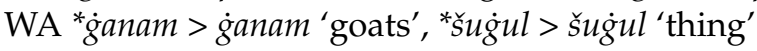

Example 5 shows that Chadian Baggara dialects (i.e., $\mathrm{BbA}, \mathrm{BaA}$ ) have a uvular implosive $G^{r}$ as basic reflex of the voiced velar fricative ${ }^{*} \dot{g}$ (Decobert 1985, pp. 45-47; Zeltner and Tourneux 1986, pp. 16, 23), whereas NA (Owens 1993a, p. 20) and KA (Manfredi 2010, p. 231) present a voiceless uvular plosive $q$, which is typical of Levantine Bedouin dialects (Rosenhouse 2006, p. 261). Similar to what is observed with $t[d$. $]$ above, in KA, the uvular implosive $\left[G^{\circ}\right]$ can occur as an allophonic realization before open vowels. Lastly, in line with ESA dialects (i.e., ShA, Reichmuth 1983, p. 46), the Baggara variety of the White Nile does not present any innovative development of the voiced velar fricative ${ }^{*} \dot{g}$. In this context, it should be also remembered that WSA sedentary dialects stand apart from Baggara dialects in that they typically present a voiceless reflex $x$ for the etymological ${ }^{*} \dot{g}$ (Roth-Laly 1994a, p. 77; Roset 2018, p. 36).

According to Owens (1993b, p. 165) the occurrence of a uvular implosive $G^{r}$ in the Chari-Baguirmi region provides strong evidence for a Fulani substratal input in WSA, as Fulani (Niger-Congo) is among the few languages in the area with implosive $G^{\circ}$. In fact, if we look at the geographic distribution of $G^{*}$ across the Baggara Belt (cf. Figure 4), it is plausible that $G^{r}$ represents an innovation emerging in Chad from a former voiced velar plosive $q$, which is still attested at the fringes of the Baggara dialect continuum (i.e., Nigeria in the west, Kordofan in the east). Furthermore, it is also true that $G^{r}$ is rarer than $d$ in the local languages spoken across the Baggara Belt. Despite this, there is no particular reason to postulate a Fulani substrate in Baggara Arabic, as the uvular implosive $G^{\prime}$ is also found in Afro-Asiatic (e.g., the Chadic languages Tera and Bole) and Nilo-Saharan (e.g., Central Sudanic-Sara-Bongo) languages spoken in the wider Lake Chad region (Maddieson 2013). In view of the above, $G^{*}$ can be better analyzed as a phonological innovation that emerged in Chad due to areal diffusion and whose geographical dispersion across the Baggara Belt is affected by both the persistence of conservative phonological features (i.e., $q$ in NA and $\mathrm{KA}$ ) and by the influence of ESA varieties (i.e., $\dot{g}$ in WA).
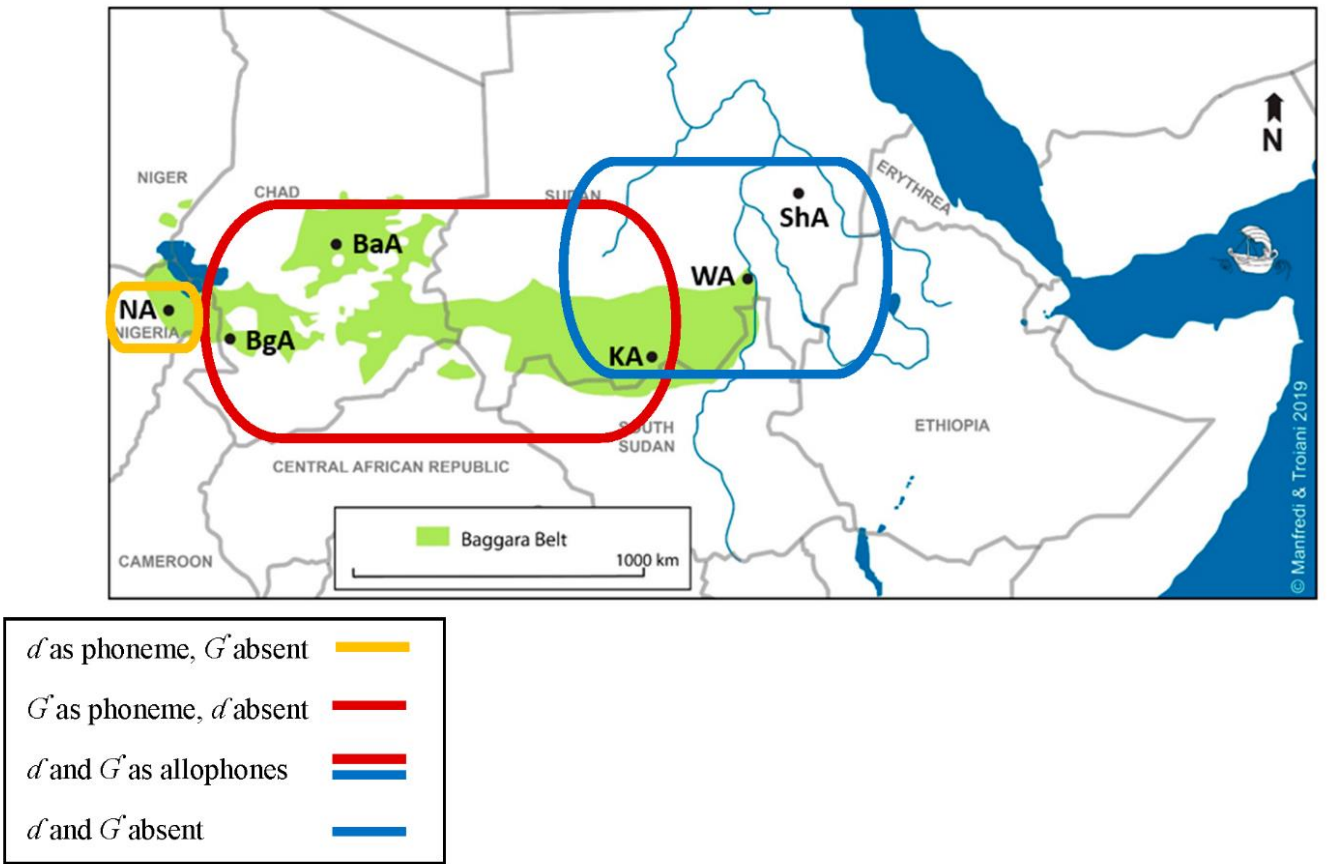

Figure 4. Implosive consonants. 
Another segmental feature that draws attention in our phonological comparison of Baggara dialects is the occurrence of the voiceless postalveolar affricate $\check{c}$ [t $\int$ ]. Owens (1993b, p. 161) and Roth-Laly (1994b, p. 77) consider č as a Pan-Sudanic feature (cf. 1). In fact, if we exclude ESA Bedouin dialects (i.e., ShA, Reichmuth 1983, p. 43), č seems to be attested all across the Sudanic dialect area. Despite this, the phonological status of $\check{c}$ varies a great deal across the Baggara Belt. In most cases, $\check{c}$ is found either in ideophones (cf. 1) or in loanwords from different local languages.

6. NA ču IDPH, čabaq 'he waded through' (wade_through.3SG.M)

BgA čat IDPH, čilal 'milvus'

$\mathrm{BaB} \quad \check{c} u t \mathrm{IDPH}$, kolči 'groundnuts'

KA čall IDPH, črorōo 'topping for sorghum'

WA čall IDPH

These non-etymological occurrences of $\check{c}$ may suggest a marginal phonemic status of this phoneme in Baggara dialects. Nevertheless, the origin of the phoneme $\check{c}$ can also be traced back to internal phonological changes.

7. NA, BgA *šakka > čakka 'he pierced' (pierce.3SG.M)

KA *šakšāka > čakčāka 'drizzle'

8. $\mathrm{BaA}, \mathrm{BgA}$ *wajh $>$ wiči 'face'

$\mathrm{KA}{ }^{*}$ wajh $>$ wičč 'face'

As we can see in the previous examples, in Baggara Arabic č may represent either a minority reflex of the etymological $\check{s}$ or the output of phonological assimilation between the voiced postalveolar affricate $j$ and a following laryngeal $h$. Still, none of these internal changes is attested in WA (e.g., šakka 'he pierced'; wašš 'face'). The weakening of the phonological status of $\check{c}$ in the White Nile region suggests a western (i.e., Chadian) origin for this phoneme.

Lastly, an interesting case of suprasegmental change that variably affects Baggara Arabic is represented by the regressive assimilation $n t>t t$ in 2 nd person independent personal pronouns (cf. Figure 5).
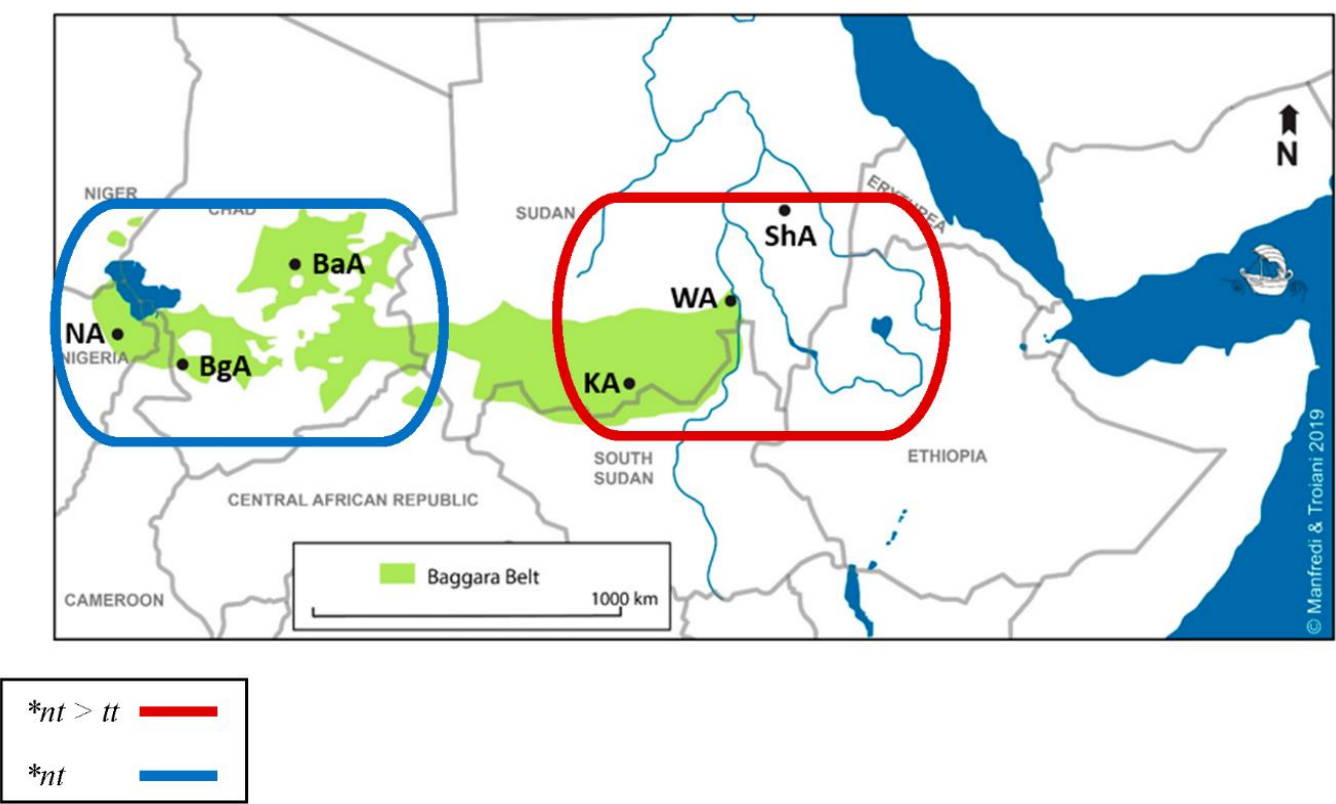

Figure 5. * $n t>t t$ in 2 nd person independent pronouns.

As we can see in Table 1, western Baggara dialects (i.e., NA, BbA and BaA) are characterized by conservative pronominal forms retaining the nasal-alveolar cluster ${ }^{*} n t$, whereas eastern Baggara dialects (i.e., KA and WA) give evidence of the regressive assimilation ${ }^{*} n t>$ 
tt. Given that Baggara Arabic as a whole is characterized by a remarkable stability of bound pronouns, ${ }^{1}$ regressive assimilation in independent pronouns suggests that free morphemes are more likely to undergo phonological change than bound morphemes. In comparative terms, the west-east split in the domain of 2 nd person independent personal pronouns proves the integration of ESA Bedouin features in eastern Baggara dialects (cf. 4.2, 4.3, 5), as the assimilation $n t>t t$ is also attested in ShA (Reichmuth 1983, p. 102).

Table 1. 2nd person independent pronouns.

\begin{tabular}{cccc}
\hline & NA, BgA, BaA & KA & WA, ShA \\
\hline 2SG.M & inta & itte & itta \\
2SG.F & inti & itti & itti \\
2PL.M & intu & uttu & ittu \\
2PL.F & intan & ittan & ittan \\
\hline
\end{tabular}

\subsection{Morphosyntactic Features}

Baggara Arabic is bound by a few innovative morphosyntactic changes that distinguish it from other WSA and ESA dialects. For example, all the Baggara dialects included in our sample elide 1st singular and 2nd singular masculine pronominal affixes in the suffixed conjugation of consonant-final verbs lacking of nominal/pronominal objects, as shown by Table 2 .

Table 2. Elision of pronominal subjects in the suffixed conjugation.

\begin{tabular}{cc}
\hline$k a t a ́ b$ write $\backslash$ 1SG & $k a t a ́ b-t=a$ write-1SG $=3 S G . M$ \\
\hline$k a t a ́ b$ write $\backslash 2$ SG.M & $k a t a ́ b-t=a$ write-2SG.M $=3 S G . M$ \\
$k a ́ t a b$ write.3SG.M & Kátab $=a$ write.3SG.M $=3 S G . M$ \\
\hline
\end{tabular}

9. KA, elision of 1st SG person in absence of nominal objects

wiṣil

arrive-1SG

'I arrived.'

wiṣil-ta kudūgli

arrive-1SG Kadugli

'I arrived in Kadugli.'

In these conditions, stress is grammatically distinctive as it distinguishes between 1st singular/2nd singular masculine and 3rd singular masculine pronominal subjects (Zeltner and Tourneux 1986, p. 72; Owens 1993a, p. 111; Manfredi 2010, p. 240). In a different manner, sedentary dialects of Chad and Sudan present the suffix - $t a$ for both 1st singular and 2nd singular masculine persons (Roth-Laly 1979, p. 2; Owens 1993b, p. 131; Dickins 2006, p. 563; Manfredi 2013, p. 15; Roset 2018, p. 177), whereas the form - $t$ seems to be limited to ESA Bedouin dialects (i.e., ShA, Reichmuth 1983, p. 281).

In contrast to the above, verbal inflection may also be affected by an important degree of diatopic variation across the Baggara Belt. This is the case of 1st singular/1st plural person marking in the prefixed conjugation.

As is well known, Arabic dialects can be broadly classified into three morphological types depending on the 1st singular/1st plural pronominal affixes of the prefixed conjugation (i.e., type-1 (b-)a-... 1SG vs. $n-\ldots$ 1PL; type-2 $a-\ldots$ 1SG vs. $n-\ldots-u$ 1PL; type-3 $n-\ldots$ 1SG vs. $n-\ldots-u$ 1PL). If type- 1 is mainly found in eastern (i.e., Levantine) Arabic dialects, type-3 is generally supposed to be a western (i.e., Maghrebi) feature spreading up to eastern Egypt. Type-2, on its part, seems to be limited to a few buffering zones in the Nile Delta and in Upper Egypt (Behnstedt 1998).

Despite important differences in their historical reconstruction, Owens and Jidda (2006) and Behnstedt (2016) agree on the fact that the attestation of type-3 in Chad is proof 
of the migration of speakers out of Upper Egypt into the Sudanic region. Nevertheless, if we look at the paradigms in Table 3, it clearly appears that the diffusion of type- 3 in Baggara Arabic is affected by both internal developments and dialect contact. On one side, Chadian Baggara dialects (i.e., BgA, BaA) present type- 3 forms $n-\ldots$ 1SG vs. $n-\ldots$ - $u$ 1PL.

Table 3. 1SG/1PL marking in prefixed conjugation.

\begin{tabular}{lcccc}
\hline & NA & BgA, BaA & KA & WA, SHa \\
\hline CvCvC 1SG & $b a-k t u b$ & $n a-k t u b$ & $(b-) a-k t u b$ & $(b-) a-k t u b$ \\
CvCvC 1PL & $n a-k t u b$ & $n a-k t u b-u$ & $n a-k t u b(-u)$ & $n a-k t u b$ \\
CvCv 1SG & $b a-m s ̌ i$ & $n a-m s ̌ i$ & $(b-) a-m s ̌ i$ & $(b-) a-m s ̌ i$ \\
CvCv 1PL & $n a-m s ̌ i$ & $n a-m s ̌-u$ & $n a-m s ̌-u$ & $n a-m s ̌ i$ \\
\hline
\end{tabular}

On the other side, WA shares with ShA a more conservative type-1 paradigm, $a-\ldots$ $1 S G$ vs. $n-\ldots$ 1PL. Nigerian Arabic, on its part, presents an innovative type-1-derived paradigm in which the preverbal marker ${ }^{*} b$ - has been integrated into the 1st singular affix ${ }^{*} a$-, i.e., $b a-1 S G$ vs. $n-\ldots$ 1PL. In light of the above, it seems plausible to think that both type- 3 and type- 1 dialects played a role in the emergence of Baggara Arabic, the former type still covering the core of Baggara Belt (i.e., Chad), with the latter now being limited to the geographical fringes of the dialect continuum (i.e., Nigeria, White Nile). In this context, KA falls again into a contact zone characterized by a mixed type 2-paradigm, $a-\ldots$ 1SG vs. $n-\ldots-u 1$ PL. It is also worth remembering that most WSA sedentary dialects present a type-3 prefixed conjugation (Roth-Laly 1979, p. 3; Jullien de Pommerol 1999b, p. 131; Roset 2018, p. 178) and that for this reason, the forms $n-\ldots$ SS vs. $n-\ldots-u$ PLL can well be considered as a WSA feature.

However, non-native varieties of Arabic in western Sudan tend to neutralize number distinction of 1st persons. Accordingly, they generalize the use of the prefix $n$ - to both 1st singular and plural persons (Manfredi 2013, p. 42). This instance of paradigm simplification by analogy (i.e., $n-\ldots$ SSG vs. $n-\ldots-u 1$ PL $>n-1$ ) proves that Baggara dialects represent the main target varieties of non-native speakers of Arabic in Chad and western Sudan. Figure 6 resumes the distribution of the pronominal prefixes of the prefixed conjugation across the Baggara Belt.
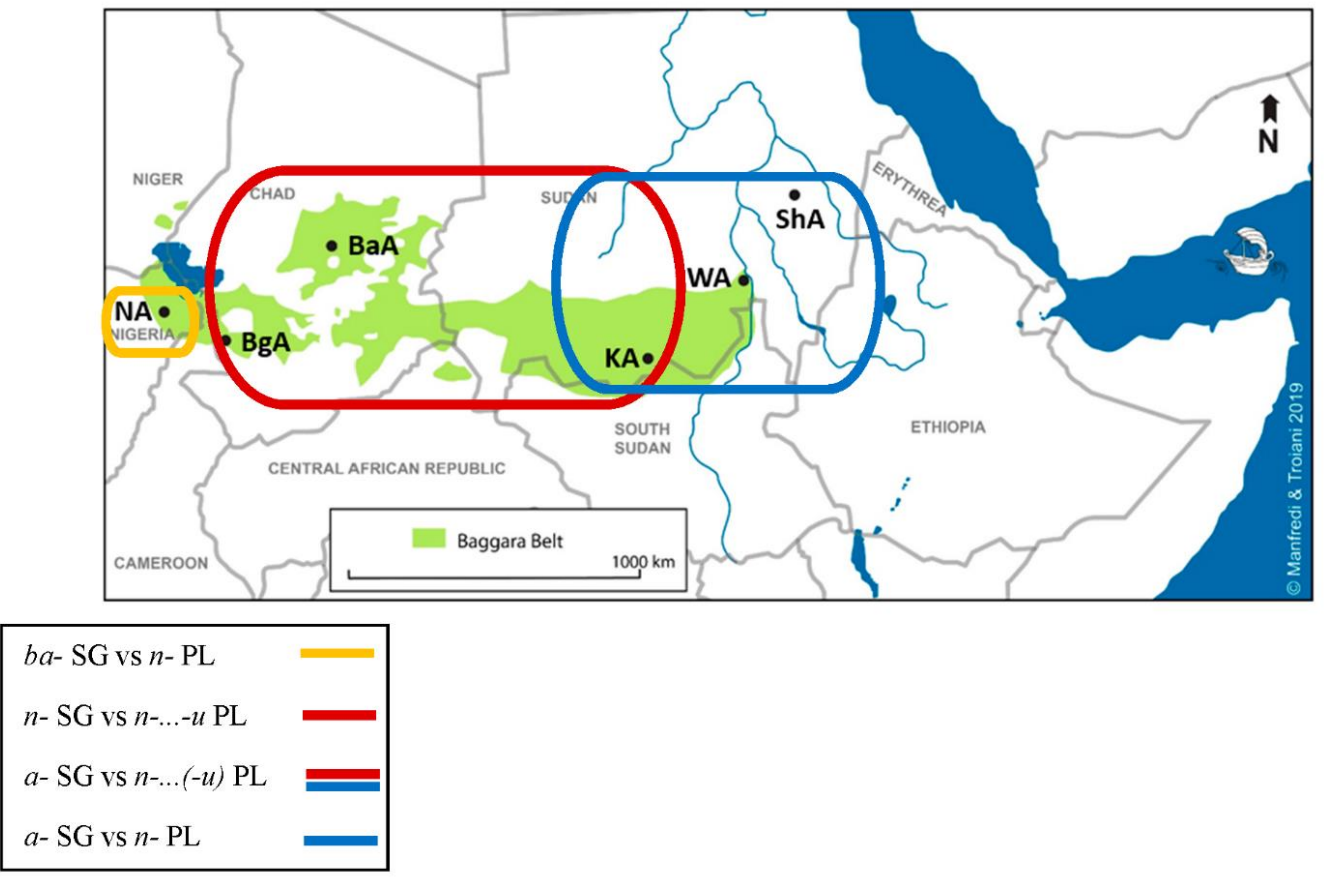

Figure 6. 1st person marking in prefixed conjugation. 
Morphosyntactic variation across the Baggara Belt can also be induced by the emergence of isolated features due to internal change. This is the case of the interrogative pronominals "who" and "which one".

10. NA, BgA miné 'who' /atú 'which (one)'

WA $\quad \min =\dot{u} I^{\prime}$ who' $^{\prime}($ who $=3 S G . M) /$ yat $=u^{\prime}$ 'which $(\text { one })^{\prime}($ which $=3 S G . M)$

KA $\quad a t=u^{\prime}$ 'who, which (one)' (which = 3SG.M)

Generally speaking, like most Arabic dialects, Baggara Arabic marks a distinction between the non-selective pronoun 'who' and the selective pronoun 'which one'. In WA, these interrogative pronominals are inflected for number and gender by means of accented clitic pronouns, whereas western Baggara dialects (i.e., NA, BbA) present two invariable pronominal forms. In this context, KA is the only Baggara dialect to express both nonselective and selective meanings by means of a single morphological form inflected for number and gender (i.e., at=, Manfredi 2010, p. 218). Given that Niger-Congo and NiloSaharan languages in contact with Baggara Arabic in the Nuba Mountain region (Southern Kordofan) formally distinguish 'who' and 'which one', this isolated feature of KA can only be imputed to an internal change not shared by other Baggara dialects.

Finally, diatopic variation in morphosyntactic structures can also be a product of the diverse impact of areal diffusion on Baggara Arabic. This kind of contact-induced change can be exemplified by two competing comparative constructions across the Baggara Belt.

11. NA, BgA, KA, exceed comparative with fät 'pass, surpass'

hajm $=i b=u-f u ̈ t=a k$

size $=$ 1SG IND = 3SG.M-surpass = 2SG.M

'I'm bigger than you.'

WA, ShA, elative form with locative marking

ana akbar $\min =a k$

1SG big from $=$ 2SG.M

'I'm bigger than you.'

Example 10 shows that, in line with most Sub-Saharan languages (Stassen 2013), Baggara Arabic presents exceed comparative constructions in which the standard is constructed as the object (i.e., =ak 2SG.M) of the transitive verb fāt 'surpass'. Still, this instance of grammatical calquing induced by areal diffusion does not reach WA which, similarly to ShA and other ESA dialects, presents a more common locational comparative construction with the standard introduced by the preposition min 'from'. The absence of exceed comparative constructions in the eastern fringes of the Baggara Belt is reasonably another output of dialect leveling towards ESA and it is another argument in favor of a west-east migration of Baggara groups.

\subsection{Lexical Features}

The Baggara dialects included in our sample share a number of interesting lexical innovations. These include the lexemes h/harrāy 'sun' (Behnstedt and Woidich 2011, p. 402) and $e l m i$ 'water' $\left({ }^{*} a l=m i<{ }^{*} a l=m \bar{a}\right.$ ? , Behnstedt and Woidich 2011, p. 420), which differ from the more common šemis/šemiš 'sun' and mōya 'water'. Furthermore, Baggara Arabic gives evidence of a few conservative lexical features, as in the case of the root " $r a ? \bar{a}$ for the verb 'see' (Behnstedt and Woidich 2014, p. 330; cf. 4.1). Despite these surface affinities, Baggara Arabic displays a high degree of lexical variation. First of all, the westernmost Baggara dialects (i.e., NA, BgA) stands out from the other varieties included in our sample due to a number of loanwords from Kanuri and other languages spoken in the Lake Chad region (Behnstedt and Woidich 2011, p. 23; 2014, p. 730).

12. NA, BgA kāka-y '(my) grandmother' (from Kanuri kàká)

BgA, KA, WA amm amm $-i$, ammạnt-i ' (my maternal) grandmother' (lit. 'the mother of my mother')

13. NA, BgA čokol 'fork' (from Hausa cóokàlii)

KA, WA šok $k a$ 'fork' 
Most commonly, lexical variation across the Baggara Belt results from dialect contact. The possessive particles (POSS) in Table 4 are a case in point.

Table 4. Possessive particles.

\begin{tabular}{|c|c|c|c|c|c|}
\hline & NA & BgA & KA & WA & ShA \\
\hline POSS.SG.M & hana & hana & $h \bar{a} n, h \bar{u} l$, & $h \bar{u} l$ & $h \bar{u} l$ \\
\hline POSS.SG.F & hil, hinta & hil & hint, hīl, & $h \bar{\imath} l$ & $h \bar{\imath} l$ \\
\hline POSS.PL & hinen & hiney & hinēn, hilēel & hilēl & hilēl \\
\hline
\end{tabular}

As we can see, western Baggara dialects (i.e., NA and BgA) are bound by the forms hana POSS.SG.M and hine(n) POSS.PL, as opposed to hül POSS.SG.M and hilèl POSS.PL in WA. Conversely, the form hil/hìl POSS.SG.F is attested all across the Baggara Belt, whereas the singular feminine form hint is limited to NA and KA. In this overall situation, KA clearly falls into a buffer zone in which western and eastern lexical forms are still in competition (Manfredi 2012). On the one hand, han(a)/hint(a)/hinēn forms originate in Upper Egypt (Owens 1993b, p. 111) and they represent a WSA feature within Sudanic Arabic as they are also attested in the sedentary dialects of Chad. On the other hand, hül/hìl/hilēl possessive particles are common to ESA dialects spoken by groups that penetrated Sudan directly from the Arabian Peninsula (i.e., ShA, Reichmuth 1983, pp. 111-12) and they are not attested in the urban dialects of eastern Sudan. The complex geographical distribution of $h \bar{a} n(a) / h i n t(a) / h i n \bar{e} n$ and $h \bar{u} l / h \bar{\imath} l / h i l e \bar{l}$ across the Baggara Belt (cf. Figure 7) seems to indicate a longstanding coexistence of these possessive forms and may corroborate the idea that speakers of ESA dialects have also been historically involved in the Baggarization process (cf. 2, 5).

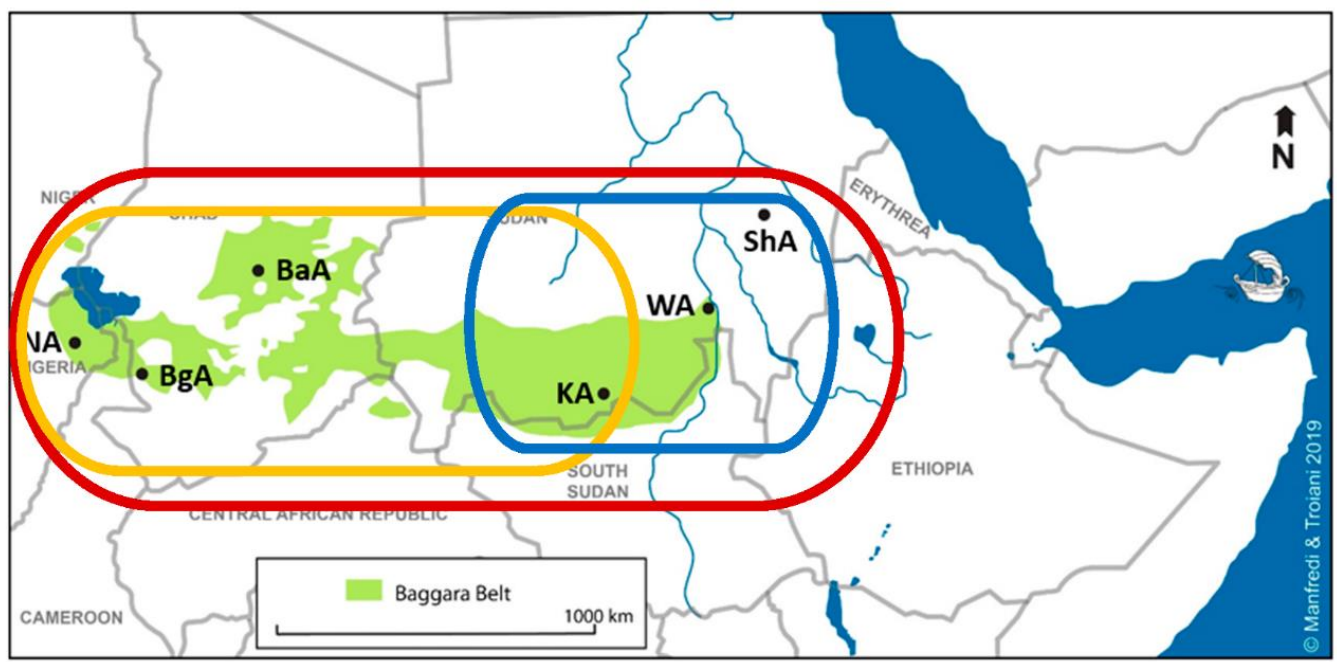

\begin{tabular}{|l|}
\hline hana, hinēn POSS.SG.M/PL \\
hūl, hilēl POSS.SG.M/PL \\
hana/hūl, hinēn/hilēl POSS.SG.M/PL \\
hīl POSS.SG.F \\
\hline
\end{tabular}

Figure 7. Possessive particles.

The intensifier 'very' provides another example of lexical variation due to dialect contact and leveling across the Baggara Belt. 


\section{NA, BgA bilhēn 'very'; BaA, KA bilhēn 'very'}

WA šedīd 'very'

In fact, except WA, all the Baggara dialects included in our sample display the form bilhēn/bilhēn, which finds its origin in the prepositional phrase *balhayl 'very' (<*bi-l-hayl 'by strength') attested in a number of Middle Eastern Bedouin dialects (Rosenhouse 2006, p. 267). WA, on its part, aligns with ESA in using the adjective *šadìd 'strong' as intensifier. This lexical isogloss confirms that the Baggara dialect of the White Nile is the most affected by contact with eastern Sudanic dialects.

\section{Conclusions}

Based on the previous comparative overview of Baggara Arabic, we can now attempt at reconstructing the main dynamics of dialect convergence and divergence across the Baggara Belt. First of all, despite their common ethnolinguistic and sociohistorical background, Baggara dialects display a high degree of diatopic variation. Indeed, if we exclude common Pan-Sudanic features (cf. 1), there are only a few isoglosses that are shared by all five varieties included in our sample. These comprise the vowel change ${ }^{*}-a>-e$ in pre-pausal position, the presence of backness vowel harmony (cf. 4.1), the forms of bound personal pronouns (cf. note 2), the elision of pronominal subjects in the prefixed conjugation (Table 2, ex. 9), and several lexical isoglosses (cf. 4.3).

Secondly, the lack of a number of WSA innovations (e.g., etymological č, ex. 7-8; bilhēen 'very', ex. 14) in the White Nile region supports the hypothesis of a west (i.e., Chad) > east (i.e., Sudan) migration of Baggara groups. In fact, if KA still gives evidence of competing WSA and ESA features (e.g., type-2 prefixed paradigm, Table 3), WA is clearly more affected by contact with ESA dialects, and therefore it is more similar to ShA (e.g., type-1 prefixed paradigm, Table 3; hūl/hilêl SG.M/PL possessive particles, Table 4). This suggests that there is no overlap between the ethnic and the dialect borders of the Baggara Belt, as WA lost most of its WSA features while integrating several ESA innovations. In this context, the attestation of both WSA and ESA features across the Baggara Belt (e.g., type-1/type-3 paradigms, Table 3; hĩl/hint F.SG possessive particles, Table 4) points to a longstanding coexistence of these dialect sub-types and provides evidence that the Baggarization process did not exclusively involved speakers of WSA varieties.

In terms of contact-induced change, we have shown that there is no linguistic evidence for a Fulani substrate in Baggara Arabic. In fact, the heterogeneity of the languages spoken across the Baggara Belt limits the possibility of a substrate interference via language shift. In such conditions, contact-induced innovations are mainly a product of areal diffusion on a west-east axis, from the Lake Chad region in direction of the White Nile. This is the case of both the implosive consonant $G^{\circ}$ (ex. 5) and exceed comparative constructions (ex. 11) whose grammatical productivity tend to fade eastwards. As far as NA and BgA are concerned, contact-induced changes also occurred as a consequence of language attrition. This is the case of depharyngealization (ex. 2) which should be seen as a relatively recent innovation induced by the high degree of Kanuri/Arabic bilingual proficiency of local sedentarized Baggara Arabs. The prominence of the adstrate over a supposed Fulani substrate is also testified by a number of loanwords occurring in the basic vocabulary of the western-most Baggara dialects (ex. 12). All things considered, NA and BgA undoubtedly represent the most innovative Baggara varieties of our sample and they cannot therefore be adopted as a dialect prototype for Baggara Arabic. Furthermore, the previous linguistic arguments potentially support the hypothesis of Baggarization as a gradual process of socioeconomic integration rather than a sudden ethnolinguistic hybridization between Arab and Fulani agro-pastoralist groups.

As a final remark, it is without doubt that Baggara Arabic as a whole represents a WSA dialect sub-type. Nonetheless, we have also shown a number of isoglosses opposing most Baggara dialects to sedentary dialects of Chad and western Sudan. These include the presence of pharyngealized and pharyngeal consonants (ex. 1-2), the presence of implosive consonants (especially $G^{r}$, ex. 5), and the elision of pronominal subjects in the 
prefixed conjugation (Table 2). This suggests that, despite the generalization of traditional Bedouin features across the Sudanic area (cf. 1), WSA is actually affected by an important eco-linguistic variation. Further to this, the structural divergences between Baggara Arabic and the sedentary dialects of Chad and western Sudan reduce the geographical extent of a number of isoglosses that were formerly thought to represent pan-WSA features (i.e., depharyngealization, implosivization). However, this is only partially true for NA and BgA that, being predominantly spoken by sedentarized Baggara Arabs, are phonologically closer to sedentary WSA dialects (ex. 3). All things considered, WSA features vary significantly according to both diatopic and eco-linguistic factors. Although there is no sharp boundary between Bedouin and Sedentary dialects in the Sudanic area, eco-linguistic factors still matter and should be therefore taken into account in further research of the area.

Author Contributions: Both authors contributed to several aspects of the study, specifically, conceptualization, S.M and C.R.; methodology, investigation, resources, and data curation S.M.; writingoriginal draft preparation S.M. and C.R.; writing, review and editing, S.M. and C.R.; supervision S.M. All authors have read and agreed to the published version of the manuscript. Both authors have read and agreed to the published version of the manuscript.

Funding: This research received no external funding.

Institutional Review Board Statement: Not applicable.

Informed Consent Statement: Informed consent was obtained from all subjects involved in the study.

Data Availability Statement: Data sharing not applicable.

Conflicts of Interest: The authors declare no conflict of interest.

\section{Abbreviations}

$\begin{array}{llll}- & \text { affix boundary } & \text { BaA } & \text { Batha Baggara Arabic } \\ = & \text { clitic boundary } & \text { BgA } & \text { Baguirmi Baggara Arabic } \\ \backslash & \text { ablaut } & \text { ESA } & \text { Eastern Sudanic Arabic } \\ * & \text { reconstructed form } & \text { KA } & \text { Kordofanian Baggara Arabic } \\ 1,2,3 & \text { 1st, 2nd, 3rd person } & \text { NA } & \text { Nigerian Baggara Arabic } \\ \text { F } & \text { feminine } & \text { ShA } & \text { Shukriyya Arabic } \\ \text { IDPH } & \text { ideophone } & \text { WA } & \text { White Nile Baggara Arabic } \\ \text { M } & \text { masculine } & \text { WSA } & \text { West Sudanic Arabic } \\ \text { OBJ } & \text { object } & & \\ \text { OBL } & \text { oblique } & & \\ \text { PL } & \text { plural } & & \\ \text { PROX } & \text { proximal } & & \\ \text { SG } & \text { singular } & & \end{array}$

\section{Note}

Among these, we can recall the forms $=a$ 3SG.M, $=k i$ 2SG.F (after both consonant- and vowel-final items) $=k u$ 3PL.M which are also variably found in the sedentary dialects of Chad and western Sudan.

\section{References}

Abu-Absi, Samir. 1995. Chadian Arabic. München and Newcastle: Lincom Europa.

Behnstedt, Peter, and Manfred Woidich. 1985. Die Ägyptisch-Arabischen Dialekte. Beihefte Zum Tübinger Atlas Des Vorderen Orients. Reihe B, Geisteswissenschaften. Wiesbaden: L. Reichert.

Behnstedt, Peter, and Manfred Woidich. 2011. Wortatlas der arabischen Dialekte, Vol. 1. Leiden: Brill.

Behnstedt, Peter, and Manfred Woidich. 2014. Wortatlas der arabischen Dialekte, Vol. 3. Leiden: Brill.

Behnstedt, Peter. 1998. La frontière orientale des parlers maghrébins en Egypte. In Peuplement et Arabisation au Maghreb Occidental. Dialectologie et Histoire. Edited by Jordi Aguadé, Patrice Cressier and Angeles Vicente. Madrid-Zaragoza: Casa de Velázquez, pp. 85-96.

Behnstedt, Peter. 2016. The niktib-niktibu issue revisited. Wiener Zeitschrift für die Kunde des Morgenlandes 106: 21-36. 
Bergman, Elisabeth M. 2002. Spoken Sudanese Arabic: Grammar, Dialogues, and Glossary. Washington: Dunwoody Press.

Blanc, Haim. 1971. Arabic. In Linguistics in Sub-Saharan Africa. Edited by Jack Berry and Thomas Albert Sebeok. Berlin: De Gruyter Mouton, pp. 501-9.

Braukämper, Ulrich. 1993. The Origin of Baggara Arab Culture with Special Rreference to the Shuwa. Sprache und Geschichte in Afrika 14: 13-46.

Carbou, Henri. 1913. Méthode Pratique pour L'étude de L'arabe parlé au Ouaday et à l'est du Tchad. Paris: Geuthner.

Čížková, Martina, Pavel Munclinger, Mame Yoro Diallo, Iva Kulichová, Mohammed G. Mokhtar, Alioune Dème, Luísa Pereira, and Viktor Černý. 2017. Genetic Structure of the Western and Eastern African Sahel/Savannah Belt and the Role of Nomadic Pastoralists as Inferred from the Variation of D-loop mtDNA sequences. Human Biology 89: 281-302. [CrossRef]

Cunnison, Ian. 1966. Baggara Arabs. Power and Lineage in a Sudanese Nomad Tribe. Oxford: Clarendon.

Cunnison, Ian. 1971. Classification by genealogy: A problem of the Baqqara belt. In Sudan in Africa. Edited by Yusuf Fadl Hasan. Khartoum: Khartoum University Press, pp. 186-96.

Decobert, Christian. 1985. Phonologies Arabes du Tchad. Paris: Geuthner.

Dickins, James. 2011. Dialects of Egypt and Sudan. In The Semitic Languages. An International Handbook. Edited by Stefan Weninger, Geoffrey Khan, Micheal Streck and Janet C. E. Watson. Berlin/Gottingen: De Gruyter Mouton, pp. 935-53.

Dickins, James. 2006. Khartoum Arabic. In Encyclopedia of Arabic Language and Linguistics, Vol. 2.. Edited by Kees Versteegh, Mushira Eid, Alaa Elgibali, Manfred Woidich and Andrzej Zaborski. Leiden: Brill, pp. 559-71.

Haaland, Gunnar. 1969. Economic determinants in ethnic processes. In Ethnic Groups and Boundaries: The Social Organization of Culture Difference. Edited by Friederik Barth. Long Grove: Waveland Press, pp. 58-73.

Hagège, Claude. 1973. Profil d'un Parler arabe du Tchad. Paris: Geuthner.

Henderson, Kenneth D.D. 1939. A note on the migration of the Messiria tribe into South West Kordofan. Sudan Notes and Records 22: 49-77.

Hillelson, Sigmar. 1925. Sudan Arabic: English-Arabic Vocabulary, 2nd ed. London: The Sudan Government.

Jullien de Pommerol, Patrice. 1999a. Dictionnaire Arabe Tchadien-Français. Paris: Karthala.

Jullien de Pommerol, Patrice. 1999b. Grammaire Pratique de l'arabe Tchadien. Paris: Karthala.

Kaye, Alan. 1976. Chadian and Sudanese Arabic in the Light of Comparative Arabic Dialectology. The Hague: Mouton.

Khalafallah, Abdelghani. 1969. A Descriptive Grammar of Sa'i:di Colloquial Egyptian Arabic. The Hague: Mouton.

Lethem, Gordon. 1920. Colloquial Arabic: Shuwa Dialect of Borno, Nigeria and of the Lake Chad Region. London: Crown Agent for the Colonies.

Lucas, Christopher, and Stefano Manfredi. 2020. Introduction. In Arabic and Contact-Induced Change. Edited by Christopher Lucas and Stefano Manfredi. Berlin: Language Science Press, pp. 1-33.

MacMichael, Harold Alfred. 1912. The Tribes of Northern and Central Kordofan. London: Frank Cass \& Co.

MacMichael, Harold Alfred. 1922. A History of the Arabs in Sudan and Some Account of the People Who Preceded Them and of the Tribes Inhabiting Dar Fur. Cambridge: Cambridge University Press, Vol. II.

Maddieson, Ian. 2013. Glottalized Consonants. In The World Atlas of Language Structures Online. Edited by Mathew Dryer and Martin Haspelmath. Leipzig: Max Planck Institute for Evolutionary Anthropology. Available online: http://wals.info/chapter/7 (accessed on 7 May 2021).

Manfredi, Stefano. 2010. A Grammatical Description of Kordofanian Baggara Arabic. Ph.D. dissertation, Università degli Studi di Napoli “L'Orientale”, Naples, Italy.

Manfredi, Stefano. 2012. Dialect mixing and dialect levelling in Kordofanian Baggara Arabic. In Dynamiques Langagières en Arabophonies: Variations, Contacts, Migrations et Créations Artistique. Hommage offert à Dominique Caubet par ses elèves et Collègues. Edited by Alexandrine Barontini, Christophe Pereira, Angeles Vincente and Karima Ziamari. Zaragoza: Universidad de Zaragoza, Colección Estudios de Dialectología Árabe, pp. 141-62.

Manfredi, Stefano. 2013. Native and Non-native varieties of Arabic in an emerging urban centre of western Sudan. Evidences from Kadugli. In African Arabic: Approches to Dialectology. Edited by Mena Lafkioui. Berlin and New York: De Gruyter, pp. 13-51.

Nováčková, Jana, Martina Čížková, Mohammed G. Mokhtar, Pavel Duda, Vlastimil Stenzl, Petr Tř́iska, Zuzana Hofmanová, and Viktor Černý. 2020. Subsistence strategy was the main factor driving population differentiation in the bidirectional corridor of the African Sahel. American Journal of Physical Anthropology 171: 496-508. [CrossRef]

Owens, Jonathan. 1985. Arabic dialects of Chad and Nigeria. Zeitschrift für arabische linguistik 14: 45-61.

Owens, Jonathan. 1993a. A Reference Grammar of Nigerian Arabic. Wiesbaden: Harrasowitz.

Owens, Jonathan. 1993b. Nigerian Arabic in Comparative Perspective. Sprache und Geschichte in Afrika 14: 85-175.

Owens, Jonathan. 2003. Arabic dialect history and historical linguistic mythology. Journal of the American Oriental Society 123: 715-40. [CrossRef]

Owens, Jonathan. 2020. Nigerian Arabic. In Arabic and Contact-Induced Change. Edited by Christopher Lucas and Stefano Manfredi. Berlin: Language Science Press, pp. 175-96.

Owens, Jonathan, and Hassan Jidda. 2006. West Sudanic Arabic. In Encyclopedia of Arabic Language and Linguistics. Edited by K. Versteegh Mushira Eid, Alaa Elgibali, Manfred Woidich and Andrzej Zaborski. Leiden and Boston: Brill, Volume IV, pp. 708-19.

Priehodová, Edita, Frederic Austerlitz, Martina Čížková, Jana Nováčková, François-Xavier Ricaut, Zuzana Hofmanová, Carina M. Schlebusch, and Viktor Černý. 2020. Sahelian pastoralism from the perspective of variants associated with lactase persistence. American Journal of Physical Anthropology 173: 423-36. [CrossRef] [PubMed] 
Reichmuth, Stefan. 1983. Der arabische Dialekt der Šukriyya im Ostsudan. Zürich: Georg Olms.

Rosenhouse, Judith. 2006. Beduin Arabic. In Encyclopedia of Arabic Language and Linguistics. Edited by K. Versteegh Mushira Eid, Alaa Elgibali, Manfred Woidich and Andrzej Zaborski. Leiden and Boston: Brill, Vol. II, pp. 259-69.

Roset, Caroline. 2018. A Grammar of Darfur Arabic. Ph.D dissertation, University of Amsterdam, LOT Publications, Amsterdam, The Netherlands.

Roth-Laly, Arlette. 1972. Esquisse de la phonologie du parler arabe d'Abbéché. Comptes Rendus du Groupe Linguistique d'études Chamito-Sémitiques (G.L.E.C.S.) 16: 33-79.

Roth-Laly, Arlette. 1979. Esquisse Grammaticale du Parler Arabe d'Abbéché (Tchad). Paris: Paul Geuthner.

Roth-Laly, Arlette. 1994a. Dialectologie comparée au Tchad et au Soudan-De quelques matériaux et discriminants. Matériaux Arabes et Sud-Arabiques 6: 69-102.

Roth-Laly, Arlette. 1994b. A propos de la pondération des discriminants dans la comparaison dialectale: Le cas de l'accent dans l'aire tchado-sudanaise. In Actes des Premières Journées Internationales de Dialectologie arabe de Paris. Edited by Dominique Caubet and Martine Vanhove. Paris: Publications Langues'O, pp. 205-16.

Schroepfer, Jason. 2016. Ethnic Variation of */ti / in Aswan Arabic. In Selected Papers from New Ways of Analyzing Variation (NWAV 44). U. Penn Working Papers in Linguistics. Philadelphia: Penn Graduate Linguistics Society, vol. 22, pp. 151-60.

Stassen, Leon. 2013. Comparative Constructions. In The World Atlas of Language Structures Online. Edited by Mathew Dryer and Martin Haspelmath. Leipzig: Max Planck Institute for Evolutionary Anthropology, Available online: http://wals.info/chapter/121 (accessed on 19 May 2021).

Teitelbaum, Joel M. 1984. The transhumant production system and change among Hawazma nomads of the Kordofan region, Western Sudan. Nomadic Peoples 18: 51-64.

Zeltner, Jean-Claude, and Henry Tourneux. 1986. L'arabe dans le bassin du Tchad. Paris: Karthala. 